\title{
Wielosektorowa współpraca w kreowaniu rozwoju regionalnego województwa mazowieckiego
}

\section{Maria Gagacka}

\section{STRESZCZENIE}

Dążenia rozwojowe współczesnych społeczeństw nierzadko mają konfliktowy charakter. Kreowanie wizji rozwoju wobec zderzania się z doraźnymi celami ekonomicznymi zarówno na poziomie polityk publicznych, jak i interesów poszczególnych jednostek i grup społecznych stwarza coraz większe trudności. Wymaga także poszukiwania nowych form rozwiązywania problemów społecznych.

W Polsce kłopoty z implementacją idei rozwoju w oparciu o współpracę międzysektorową wiążą się ze zróżnicowaniem regionalnym, a także zróżnicowaniem w obrębie regionów. Pojawienie się w polityce rozwoju na poziomie regionalnym - obok sfery publicznej i prywatnej - trzeciego sektora, przyczyniło się do poszukiwania innowacyjnych form współpracy i nowych metod rozwiązań kwestii społecznych. Celem opracowania jest analiza skali zaangażowania trzeciego sektora, ich rola w budowaniu regionalnej polityki i wpływ na rozwój województwa mazowieckiego.

Słowa kluczowe: rozwój regionalny, polityka publiczna, współpraca międzysektorowa, trzeci sektor, województwo mazowieckie

\section{Wprowadzenie - cel i metoda analizy}

Współczesne państwa w XXI w. muszą poszukiwać nowych instrumentów ważnych dla rozwoju społecznego i zaspokajania potrzeb obywateli poprzez rozszerzanie spektrum podmiotów zaangażowanych w świadczenie usług społecznych i zarządzanie nimi.

Poszukiwanie nowych rozwiązań w tym zakresie prowadzi ku zyskującemu na znaczeniu - zarówno teoretycznie jak i aplikacyjnie - paradygmatowi pluralizmu. Zaspokajanie potrzeb jednostkowych i społecznych odpowiadajacych obiektywnym wymaganiom i aspiracjom członków zbiorowości wymaga tworzenia warunków instytucjonalnych. Samorząd terytorialny uznawany jest za podstawową formę ładu społecznego demokratycznych i obywatelskich społeczeństw [Barański, Kantyka, Kubas, Kuś 2007].

Promotorzy odrodzenia idei samorządności - M. Kulesza, A. Piekara i J. Regulski - zwracali uwagę, iż rozwój samorządności nie jest celem samym w sobie, lecz ma spełniać postulaty rozwojowe oraz przeobrażać lokalną scenę polityczną. A. Piekara wskazał na aksjologiczne fundamenty reformy samorządowej: „samorządność, demokrację i podmiotowość społeczna traktowano jako wartości wzajemnie się dopełniające i nawzajem uwarunkowane" [Piekara 1991, s. 76]. 
B. Gąciarz podkreślała, iż samorządność jest formą rządzenia stosowaną w zbiorowościach, społecznościach i wspólnotach, cieszących się określoną autonomią względem społeczeństwa globalnego i jego instytucji [Gaciarz, Bartkowski 2012, s. 10]. Dynamika przemian gospodarczych i społecznych, a także dyskurs nad kierunkiem rozwoju społecznego w skali Europy sprawiaja, że rozszerzono pojęcie środowiska, nie tylko na sfere przyrody, ale także otoczenia społecznego i kultury, a za drogowskaz rozwoju uznano rozwój zrównoważony.

Rynkowe regulacje kształtujące stosunki ekonomiczne i ich funkcjonowanie - jako jeden z wyznaczników ładu gospodarczego - zmieniaja także relacje społeczne, odciskając swe piętno na oczekiwanych wzorcach działania zarówno jednostek, jak i instytucji. Rozwój społeczny, w jego obecnym zróżnicowanym kształcie, jest z jednej strony wyznacznikiem postaw, zachowań, kierunków rozwoju, demonopolizacji, demokratyzacji, decentralizacji, a nawet destrukcji kulturowych i społecznych systemów wartości i norm, z drugiej zaś strony przemianom tym towarzyszą właściwe globalizacji tendencje do standaryzacji w wielu wymiarach: technologii, idei, dominacji globalnych instytucji itd. W tym kontekście idea zrównoważonego rozwoju może być rozumiana jako koncepcja rozwiązywania czy też tylko łagodzenia napięć, tak, aby ludzkość mogła się rozwijać zaspokajając potrzeby dzisiejsze, nie zagrażając równocześnie prawu przyszłych pokoleń do spełniania swoich potrzeb.

Celem niniejszego opracowania jest przedstawienie potencjału organizacji pozarządowych w województwie mazowieckim i możliwości zaangażowania tego sektora w proces kreowania rozwoju regionu. Jest to region o znaczących dysproporcjach i wielowymiarowym zróżnicowaniu społecznym [Gagacka 2007, s. 27-35]. Ich działania, podejmowane w wielu płaszczyznach, odwołują się do dobra wspólnego i stają się elementem budowania podstaw ładu społecznego i świadomości obywatelskiej mieszkańców regionu ${ }^{1}$. Potencjał, struktura i zaangażowanie obywatelskie są fundamentalnymi warunkami współpracy międzysektorowej i współzarządzania, jako endogenicznego czynnika rozwoju regionalnego.

$\mathrm{W}$ badaniu postawiono następujące pytania badawcze:

1. Jaki jest potencjał i struktura sektora pozarządowego województwa mazowieckiego na tle kraju?

2. Jakie formy prawne dominują wśród organizacji pozarządowych?

3. Jaki jest udział organizacji pożytku publicznego w strukturze podmiotów sektora $\mathrm{w}$ regionie?

4. Jak miasto stołeczne Warszawa wpływa na obraz instytucjonalnego zaangażowania społecznego w województwie mazowieckim?

Odpowiedzi na powyższe pytania pozwolą zweryfikować następującą hipotezę: zróżnicowanie terytorialne potencjału organizacji pozarządowych jest czynnikiem ograniczającym współpracę sektorową na poziomie powiatów, a tym samym stanowi barierę pełniejszego wykorzystania endogenicznych determinantów rozwoju.

\footnotetext{
${ }^{1}$ Niniejsze opracowanie jest pierwszą częścią analizy oddziaływania sektora pozarządowego w województwie mazowieckim. Zostało oparte na przygotowanej przez autorkę ekspertyzie Zaangażowanie obywatelskie jako endogeniczny czynnik rozwoju na poziomie regionalnym Mazowsza. Perspektywa działalności organizacji pozarzadowych w sferze ustug społecznych na poziomie powiatów.
} 
Badanie zostało przeprowadzone metodami jakościowymi. Obejmowały one krytyczną analizę literatury przedmiotu, statystyk publicznych, sprawozdań i analiz, stron internetowych wszystkich powiatów województwa mazowieckiego - zakładki dotyczące sektora pozarządowego, centrów organizacji pozarządowych. Przyjętym sposobem segregowania informacji było kryterium obszaru (ów) działania wskazanych przez badane podmioty (wyłączono z części analiz szczegółowych m.st. Warszawę). Aktywność sektora pozarządowego w stolicy znacząco odbiega od skali i obszarów zaangażowania obywatelskiego $\mathrm{w}$ powiatach regionu, co zniekształca obraz tego zaangażowania w skali całego województwa. Wyniki analiz zostały przedstawione w ujęciu terytorialnym, ze szczególnym ukazaniem powiatów o dużym/małym nasyceniu zaangażowaniem obywatelskim.

\section{Organizacje pozarządowe jako partnerzy współpracy lokalnej}

Organizacjom pozarządowym przypisuje się szerokie znaczenie w życiu społecznym. Odgrywają one coraz większą rolę pomiędzy państwem i rynkiem, budując powoli, lecz systematycznie nowe reguły ładu, charakterystyczne dla społeczeństwa obywatelskiego. Funkcja pośrednika pomiędzy społeczeństwem a rynkiem (gospodarką) i państwem w świadczeniu usług społecznych i realizacji innych istotnych celów będzie czynnikiem rozwoju trzeciego sektora, a także źródłem zwiększania różnorodności form i metod osiagania celów społecznych.

Zdefiniowanie organizacji pozarządowych oraz wskazanie ich specyfiki i istoty nie jest łatwym przedsięwzięciem. Problem z ich jednoznacznym określeniem wynika z trudności terminologicznych, mnogości i niejasności pojęć, zamiennym ich stosowaniu, podkreślaniu odmiennych akcentów czy też różnym pozycjonowaniu w relacji do innych podmiotów.

Wśród najczęściej używanych określeń pojawiają się terminy: organizacja pozarządowa, organizacja non-profit (niekomercyjna, niezarobkowa, nienastawiona na zysk) oraz trzeci sektor. Pierwsze dwa określenia charakteryzuja relacje w stosunku do sektora publicznego czy komercyjnego. P. Gliński definiuje organizacje pozarządowe jako „specyficzne, współczesne formy samoorganizacji społecznej, struktury integrujące grupy obywateli, charakteryzujące się względnie dojrzałą tożsamością społeczna, określonym stopniem zorganizowania, prywatnym charakterem inicjatywy, dobrowolnością uczestnictwa, niezależnością i niekomercyjnościa, a także - na ogół - znacznym udziałem wolontariatu i istotną rolą w kształtowaniu postaw ludzkich (zarówno osób działających w organizacjach, jak i posiadających jakikolwiek z nim kontakt)" [Gliński 2006, s. 17].

Autor podkreśla, iż z istoty powyższej definicji wynika też ich charakter: organizacje pozarządowe to instytucje prywatne - w tym sensie, że powoływane są do życia i działaja dzięki wspólnej woli zrzeszonych w nich obywateli, a nie na skutek decyzji instytucji publicznych (państwowych, rządowych, samorządowych). Niekiedy w tym kontekście mówi się też o oddolności powstawania organizacji pozarządowych (grass roots organizations). 
Z kolei najwcześniej używane określenie „trzeci sektor” funkcjonuje już od lat 70. XX w. [Seidel, Anheier 1990, s. 7]. Ma on normatywne i strategiczne konotacje, opiera się na prywatnych i pozarządowych instytucjach, które nie są nastawione na zysk, a jedynie na zaspokojenie określonych potrzeb społecznych [Kuti 1989, s. 4]. Zalicza się do niego zarówno organizacje non-profit, jak i podmioty gospodarki społecznej w postaci spółdzielni i towarzystw pomocy wzajemnej. Ponadto w obszar działalności trzeciego sektora włącza się działalność samorządów lokalnych oraz przedsiębiorstw społecznych. Termin trzeci sektor odnosi się do podmiotów tworzonych w obrębie społeczeństwa obywatelskiego, które koncertują swoją działalność na doradztwie, redystrybucji i produkcji [Defourny 2004, s. 4-7]. Wielość cech i funkcji realizowanych przez podmioty sektora non-profit sprawia, iż trudno jest precyzyjnie wskazać ich istotę [Salomon, Anheier 1992].

Ważną rolę w tym sektorze odgrywaja podmioty nieformalne. Ów niezinstytucjonalizowany obszar działania w sektorze usług społecznych pomaga w rozwiązywaniu problemów społecznych. Te nieformalne grupy wsparcia formułuja się w obrębie rodziny, grup sassiedzkich czy przyjacielskich. Wsparcia udziela zarówno społeczność lokalna, jak i inni dotknięci podobnymi problemami czy też podzielającymi wspólne wartości, tworząc grupy samopomocy. Specyfika tej pomocy jest następująca:

- motywacja i obowiazzki stron wynikają z takich postaw i wartości, jak: humanitaryzm, lojalność, empatia, prospołeczność;

- pomoc udzielana jest zarówno regularnie, jak i czasowo, w sytuacjach trudnych;

- $\quad$ wsparcie opiera się przede wszystkim na zasadach współżycia społecznego, rzadziej na przepisach prawa;

- $\quad$ pomoc jest w zasadzie świadczona bezpłatnie, bez formalizacji w postaci umów między partnerami;

- wsparcie jest przekazywane na zasadach prywatnych, zarówno w obrębie kręgów wsparcia, jak i pomiędzy nimi;

- $\quad$ wsparcie jest dyskretne, a przez to niestygmatyzujące [Gagacka 2008, s. 36-37].

Doceniajac zinstytucjonalizowane, jak i nieformalne podmioty tworzace ten sektor A. Evers i J.L. Laville podkreślili, że tworzą one mechanizmy wytwarzania bogactwa innymi metodami niż wymiana rynkowa i dystrybucja publiczna, prezentują cały wachlarz działań społecznych opartych na różnych formach solidarności [Evers, Laville 2004, s. 36-38].

Biorac pod uwage cechy, jakie powinien spełniać ten sektor J. Hrynkiewicz proponuje, aby używać w odniesieniu do tych podmiotów określnika "obywatelskie" [Hrynkiewicz 2002, s. 71]. Jej zdaniem nazwa najbardziej uzasadnioną zarówno tradycja, jak i współczesnym charakterem i funkcja, jest termin organizacje obywatelskie, jako instytucje społeczeństwa obywatelskiego. W ustroju demokratycznym społeczeństwo obywatelskie to pewien idealnie wyobrażony i tworzony przez wspólnotę wolnych obywateli ład społeczny. To także proces budowania ładu opartego na wspólnych wartościach. Zasadniczym warunkiem powstania i rozwoju organizacji obywatelskiej jest aktywność jednostek i grup społecznych, rozumiana jako ich udział w zorganizowanych formach przez wspólne określanie celów, zasad, metod i form działania, tworzenie warunków i uczestnictwo 
w działaniach. Poprzez tak rozumianą aktywność tworzy się społeczne kręgi samopomocy, samoorganizacji i kontroli społecznej w stosunku do sfery publicznej [Hrynkiewicz 2002, s. 62-63]. Bez względu jednak na przyjętą terminologię podmioty te odgrywają fundamentalną rolę w społecznej przestrzeni. Kreują społeczny kontekst aktywności i wspólnych przedsięwzięć.

\section{Rozwój zrównoważony - perspektywa regionalna}

Na świecie rozwój zrównoważony jest pojmowany jako proces wyważony wspólnymi interesami: społecznymi, ekonomicznymi i środowiskowymi. Przyjmuje się, że im to wyważenie będzie doskonalsze, tym samym realizacja strategii tego rozwoju będzie bardziej efektywna. Wynika to z ogólnych założeń rozwoju zrównoważonego:

- realizowany jest przez ludzi z myślą o sobie i przyszłych pokoleniach,

- opiera się na równoważności interesów ekonomicznych, środowiskowych oraz społecznych.

Strategie wdrażania rozwoju zrównoważonego można analizować na różnych poziomach: globalnym, europejskim, krajowym, regionalnym czy lokalnym. Poziomem, na którym szczególnie często dokonuje się strategicznych analiz rozwoju zrównoważonego jest region. Problematyka regionalna odnosząca się do wielopłaszczyznowych i wielorodnych zjawisk i procesów społeczno-politycznych wymaga podejścia interdyscyplinarnego. W ujmowaniu tej kategorii akcentuje się - w zależności od specyfiki dyscypliny - aspekty: administracyjne, demograficzne, socjologiczne, ekonomiczne, polityczne, geograficzne (w tym przyrodnicze), historyczne, kulturowe, językowe, wyznaniowe i etniczne.

W kontekście omawianej w tym opracowaniu problematyki najbardziej adekwatne jest podejście społeczno-kulturowe, w którym region jest postrzegany jako terytorium charakteryzujące się podobnym stylem życia jednostek go zamieszkujących. Podobieństwo sytuacji życiowej staje się czynnikiem integracji społeczności, która z właściwym sobie modelem życia tworzy wspólnotę wynikającą z poczucia solidarności. Jednostka terytorialna zamieszkiwana przez określona grupę ludzi wykazuje więc skłonność do integracji wokół wspólnie wyznawanych wartości kulturowych i religijnych. Wyrazem tej integracji jest kształtująca się świadomość regionalna [Kwilecki 1992, s. 37-39].

Samorząd terytorialny stanowi całość społeczna, która spełnia rozmaite funkcje i obejmuje zakresem swojej aktywności wiele różnych obszarów. Istotą rozwojowej misji samorządów jest:

- adekwatne zaspokajanie potrzeb społeczności terytorialnych poprzez zapewnienie warunków ich zrównoważonego rozwoju;

- mobilizowanie zasobów kapitału ludzkiego i społecznego do rozwoju społeczności poprzez utrwalanie jej więzi społecznych i tożsamości kulturowej;

- $\quad$ trwałe poszerzanie społecznej bazy rozwoju, zaangażowanie obywateli w działania prorozwojowe poprzez ustanowienie takich standardów tworzenia polityk publicznych, 
w których dialog społeczny i odpowiedzialność demokratyczna są trwałymi składnikami procesu politycznego;

- odpowiedzialne zarządzania zasobami naturalnymi i kapitałowymi społeczności, które zapewnia trwałość jej zdolności rozwojowych [Gąciarz, Bartkowski 2012, s. 10].

Warto podkreślić, iż region jest przestrzenia, w której stykają się konkretne interesy społeczności lokalnej oraz interesy abstrakcyjnie ujmowanego społeczeństwa, utożsamianego często z państwem. Przestrzeń ta umożliwia budowanie partnerskich relacji i prowadzenie dialogu zarówno z obywatelami, jak i społecznościami lokalnymi. Staje się instrumentem komunikacji między obywatelami a władzą. Oczekiwania społeczne na poziomie regionu sa łatwiejsze do określenia w odróżnieniu od dążeń ogólnokrajowych. Mieszkańcy danego regionu oczekuja od władz regionalnych podejmowania takich konkretnych działań, które w efekcie przyniosa - zarówno bezpośrednio, jak i pośrednio - realne korzyści dla mieszkańców, w krótkim i długim okresie [Tomaszewski 2007, s. 47-101].

Unia Europejska uczyniła z rozwoju regionalnego jeden z podstawowych filarów spójności Wspólnoty. Wychodząc z założenia, że władze lokalne i regionalne odgrywaja dominującą rolę $\mathrm{w}$ procesach modernizacyjnych i rozwojowych, obarczono je szczególną rola i odpowiedzialnością w kreowaniu wizji i warunków rozwoju.

O kształcie i tempie rozwoju regionalnego i lokalnego decydują obecnie inne, zróżnicowane czynniki. Tradycyjne kryteria „ilościowe” odgrywają coraz mniejszą rolę, natomiast szczególnego znaczenia nabierają czynniki jakościowe, związane m.in. z potencjałem badawczo-rozwojowym regionu oraz ogólnym klimatem dla przedsiębiorczości i rozwoju instytucji ją wspierających [Jałowiecki, Szczepański 2002, s. 231-236].

Z punktu widzenia tak rozumianego rozwoju regionalnego, którego podstawę stanowią: przedsiębiorczość, konkurencyjność i innowacyjność, najważniejszymi czynnikami decydującymi o jego potencjale są:

- podmiotowość regionu, czyli świadomość własnej siły, kultury i wartości, oferowanych przez społeczność zewnętrznemu otoczeniu globalnemu;

- $\quad$ rozwijanie nowej wiedzy, kompetencji i kwalifikacji potrzebnych do uzyskania istotnej przewagi konkurencyjnej w międzyregionalnym podziale pracy, zwłaszcza w zakresie efektywnej kooperacji i współdziałania na rzecz rozwoju;

- zaktywizowanie sił społecznych gwarantujących realizację przyjętej wizji i kierunku rozwoju;

- działanie na rzecz identyfikacji i znoszenia między nimi barier rozwojowych;

- wykorzystywanie układów powiązań, sił i środowisk do współdziałania w celu rozwoju własnego regionu.

Ważną rolę we współczesnych koncepcjach rozwoju regionalnego odgrywają czynniki wewnętrzne, endogenne. Podstawowymi wyznacznikami rozwoju endogennego są: tożsamość kulturowa, zharmonizowanie nowoczesności z własną tradycją oraz szeroka partycypacja społeczna [Krzysztofek, Szczepański 2002, s. 207-210]. Wymogiem rozwoju endogennego jest zatem szerokie w nim uczestnictwo społeczeństwa, a także wyzwolenie społecznej energii i kreatywności. 
Rozwój endogenny na poziomie regionalnym ujmowany jest jako proces,w którym znaczącą rolę odgrywają potrzeby, inicjatywy i kompetencje członków społeczności, zaś impulsami rozwojowymi są uwarunkowania kulturowe, możliwości i realia regionów [Herbst 2007, s. 66-69].

Jak widać z przedstawionego powyżej katalogu czynników rozwojowych, dynamiczny i harmonijny rozwój regionu jest wynikiem stosowania zasad pluralizmu społecznego, według którego nie można stawiać państwa w uprzywilejowanej pozycji, ale jak najwięcej swobody i podmiotowości pozostawiać wspólnotom bliskim człowiekowi - gminom, regionom czy też grupom obywateli zorganizowanych wokół określonych problemów.

\section{Współpraca wielosektorowa w kreowaniu rozwoju regionalnego}

Jedna z bardziej widocznych w ostatnich dekadach tendencji w polityce publicznej jest nowy model pluralizmu - wielosektorowości (welfare pluralism). Charakteryzuje się różnorodnościa systemów wartości i norm. Podmioty społeczeństwa obywatelskiego stanowia niezbędny instrument w polityce regionalnej, wzbogacający jej przestrzeń i cele nie tylko o te oddziaływania, które kształtują warunki życia, lecz także umacniają więzi społeczne. Pluralistyczna polityka regionalna może stać się narzędziem budowy i umacniania społeczeństwa obywatelskiego. J. Supińska podkreśla, że współpraca i współdziałanie trzech sektorów tworzących trójkąt dobrobytu, wzbogacone sektorem nierynkowym (stanowi go środowisko rodzinne, sąsiedzkie, przyjacielskie) jest przyszłością systemów polityki publicznej w sferze usług społecznych [Supińska 2009, s. 235-247].

M. Grewiński - propagator modelu wielosektorowości podkreśla znaczenie zróżnicowania sektorowego i odmiennych właściwości działania poszczególnych sektorów [Grewiński 2006, s. 7]. W każdej z tych sfer działają różnorodne podmioty, które ze względu na swoja specyfikę instytucjonalną (wartości, zasady, reguły, normy, finansowanie) wpisują się w poszczególne sektory. Charakterystyczna cechą wszystkich koncepcji welfare pluralism jest wskazanie na rosnąca rolę sektorów niepublicznych (komercyjnych i społecznych). Współdziałanie trzech partnerów: państwa, podmiotów rynkowych, organizacji pozarządowych i innych podmiotów realizujacych cele społeczne jest najbardziej skutecznym sposobem ograniczenia problemów społecznych, których nie da się rozwiązać w separatystycznej formule.

Organizacjom stanowiącym emanację sektora pozarządowego przypisuje się szerokie znaczenie w życiu społecznym. Odgrywają one coraz większą rolę pomiędzy państwem i rynkiem, budując powoli, lecz systematycznie nowe reguły ładu charakterystyczne dla społeczeństwa obywatelskiego. Funkcja pośrednika pomiędzy społeczeństwem a rynkiem (gospodarka) i państwem w świadczeniu usług społecznych i realizacji innych społecznie istotnych celów jest czynnikiem rozwoju trzeciego sektora, a także źródłem zwiększania różnorodności form i metod osiagania celów społecznych.

J. Hrynkiewicz podkreśla, że w ustroju demokratycznym społeczeństwo obywatelskie buduje ład oparty na wspólnych wartościach. Zasadniczym warunkiem powstania i rozwoju 
organizacji obywatelskiej jest aktywność jednostek i grup społecznych, rozumiana jako ich udział w zorganizowanych formach poprzez wspólne określanie celów, zasad, metod i form działań, tworzenie ich warunków i uczestnictwo w nich. Poprzez tak rozumiana aktywność tworzą się społeczne kręgi samopomocy, samoorganizacji i kontroli społecznej w stosunku do sfery publicznej [Hrynkiewicz 2002, s. 71].

Korzyści z tak rozumianego rozwoju zrównoważonego są ogromne, bowiem szybka adaptacja do nowych warunków współdziałania nabiera coraz większego znaczenia przy tempie współczesnych przemian gospodarczych i cywilizacyjnych. Aktywizuje się przy tym nie tylko sfera makro, ale także mikro. Dzięki takiemu podejściu na poziomie lokalnym zwiększają się szanse na wykorzystanie aktywności miejscowych społeczności i rośnie autentyczny ich udział w kreowaniu procesów rozwoju i kontroli ich realizacji oraz uwzględniania w procesach rozwoju kryteriów jakości.

Pojawienie się w polityce rozwoju na poziomie regionalnym - obok sfery publicznej i prywatnej - trzeciego sektora, przyczyniło się do poszukiwania innowacyjnych form współpracy i nowych metod rozwiązywania kwestii społecznych [Gagacka 2009, s. 443-468].

Jednym z przejawów takiego nowego podejścia jest widoczny wzrost zainteresowania zarówno badaczy, jak i samorządowców kwestiami endogenicznych czynników rozwoju w skali regionów i społeczności lokalnych.

\section{Potencjał sektora pozarządowego - województwo mazowieckie na tle kraju}

Potencjał trzeciego sektora jest w Polsce przedmiotem analiz nie tylko w instytucjach odpowiedzialnych za gromadzenie i przetwarzanie danych, ale także w wielu podmiotach pozarządowych zainteresowanych wspieraniem go czy też współpracą z nim, jak również budowaniem i rozwijaniem społeczeństwa obywatelskiego.

Dane GUS wskazuja, że w 2018 r. na terenie Polski aktywnie działało 88,1 tys. rejestrowych organizacji non-profit, (tj. mających osobowość prawną stowarzyszeń i podobnych organizacji społecznych, fundacji, społecznych podmiotów wyznaniowych oraz organizacji samorządu gospodarczego i zawodowego), wśród których najliczniejsza grupa były stowarzyszenia i podobne organizacje społeczne (69,1 tys.; 78,4\%), a następnie fundacje (14,5 tys.; $16,5 \%$ ). W badanej zbiorowości, co 10 jednostka miała status organizacji pożytku publicznego (9,3 tys.). Z kolei podmioty ekonomii społecznej stanowiły 99,1\% - 87,3 tys. aktywnych organizacji (w tym 0,2 tys. znajdowało się na liście przedsiębiorstw społecznych prowadzonej przez MRPiPS). Warto podkreślić, że pomiędzy 2010 r. a 2018 r. liczba aktywnych organizacji w skali kraju zwiększyła się o 10,0\% (z 80,1 tys. do 88,1 tys.) [GUS 2019] (ryc. 1).

Największa część podmiotów non-profit mających osobowość prawną miała swoje siedziby w województwie mazowieckim - 13,4 tys. (15,2\%). Kolejnym województwem pod względem liczebności aktywnych organizacji było wielkopolskie - 8,7 tys. (9,9\%), a trzecim - małopolskie - 8,7 tys. (9,8\%). W przeliczeniu na 10 tys. ludności najwięcej organizacji non-profit w Polsce miało swoje siedziby w województwie małopolskim - 25,5, a najmniej w ślaskim - 17,3. 


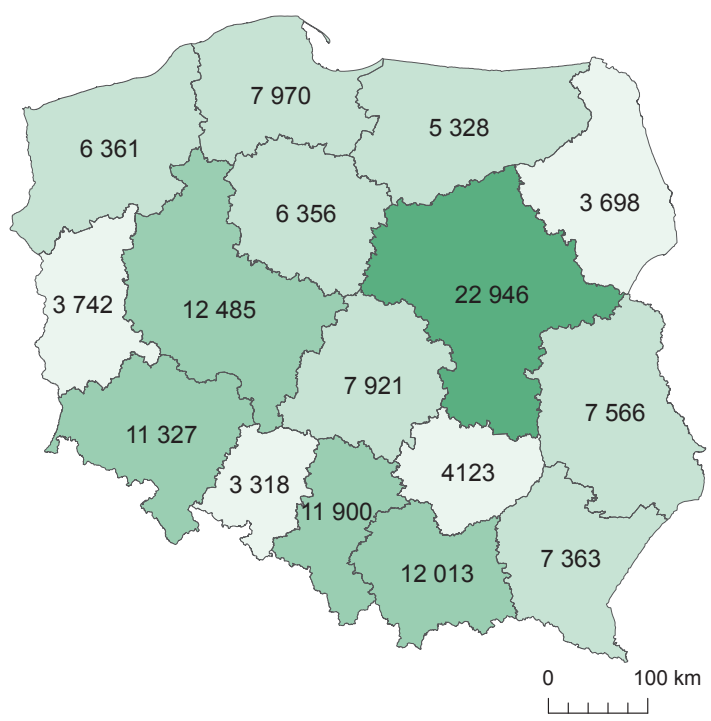

Ryc. 1. Liczba stowarzyszeń i fundacji na początku 2018 r. (dane w liczbach bezwzględnych) Źródło: dane GUS 2019, https://api.ngo.pl/media/get/108904

Warto podkreślić, że aż połowa organizacji pozarządowych w województwie mazowieckim to jednostki z siedzibą na terenie Warszawy, a blisko 1 / 4 wszystkich fundacji działających w kraju zlokalizowana jest także w stolicy, zaś 27,5\% fundacji miało siedziby na terenie województwa mazowieckiego [GUS 2019, s. 2]. Województwo wielkopolskie natomiast charakteryzowało się na tle całej Polski największym odsetkiem kółek rolniczych (28,3\%), a wśród społecznych podmiotów wyznaniowych dominowały organizacje z siedzibą w województwie mazowieckim $(16,9 \%)$, a następnie w małopolskim (15,3\%).

Analizy GUS, ze względu na ograniczony zakres gromadzonych danych, dotycza wyłącznie organizacji rejestrowych, czyli mających osobowość prawną [GUS 2019, s. 2]. Jednakże GUS wstępnie ocenił także skalę zaangażowania obywatelskiego w mniej sformalizowane organizacje społeczne, niemające osobowości prawnej. Na podstawie deklaracji starostw powiatowych i urzędów miast na prawach powiatów oraz danych Instytutu Statystyki Kościoła Katolickiego oszacowano, że w 2018 r. na terenie kraju funkcjonowało 5,9 tys. stowarzyszeń zwykłych oraz działało 65,5 tys. organizacji parafialnych Kościoła Katolickiego. Organizacje pozarządowe w Polsce maja mocno zdywersyfikowane sfery aktywności. Najbardziej rozpowszechnionymi jej formami są: sport, rekreacja i działania związane z czasem wolnym. Także oddziaływania kulturalne i edukacyjne obejmuja znaczacy obszar tych aktywności. Na tym tle znacznie mniejszą rolę odgrywają działania proekologiczne.

W odniesieniu do współpracy międzysektorowej istotną kwestię stanowi finansowanie działalności podmiotów obywatelskich. Dominującym źródłem ich finansowania są krajowe (39\%), następnie zagraniczne środki publiczne, a także odpłatna działalność gospodarcza $(15 \%)$ oraz filantropia instytucjonalna $(15 \%)$ i indywidualna $(14 \%)$. Znaczacy udział finan- 
sów publicznych, w połączeniu z krótkookresowym i częściowym współfinansowaniem wybranych i zlecanych przez administracje rządową i samorządowa programów i działań sprawia, że nadal utrzymuje się podrzędna pozycja organizacji społecznych wobec administracji publicznej, a zwłaszcza jednostek samorządu terytorialnego [Leś 2018, s. 478].

W analizie zaangażowania obywatelskiego, jako wyznacznika kapitału społecznego $\mathrm{w}$ kontekście rozwoju regionalnego, kluczową kwestią - zgodnie z założonym celem tego badania - jest ocena potencjału zaangażowania sektorowego mieszkańców województwa mazowieckiego. Dane krajowe stanowią tu tylko ogólny punkt odniesienia.

Do organizacji pozarządowych zalicza się szerokie spektrum podmiotów. Ustawa z dnia 24 kwietnia 2003 r. o działalności pożytku publicznego i wolontariacie określa ich konstytutywne cechy. Zgodnie z tymi zapisami tworza je zarówno stowarzyszenia i fundacje, jak i zróżnicowana grupa innych jednostek nienależących do sektora finansów publicznych i niedziałających dla zysku.

Strukturę podmiotów tworzacych trzeci sektor w województwie mazowieckim przedstawia rycina 2.

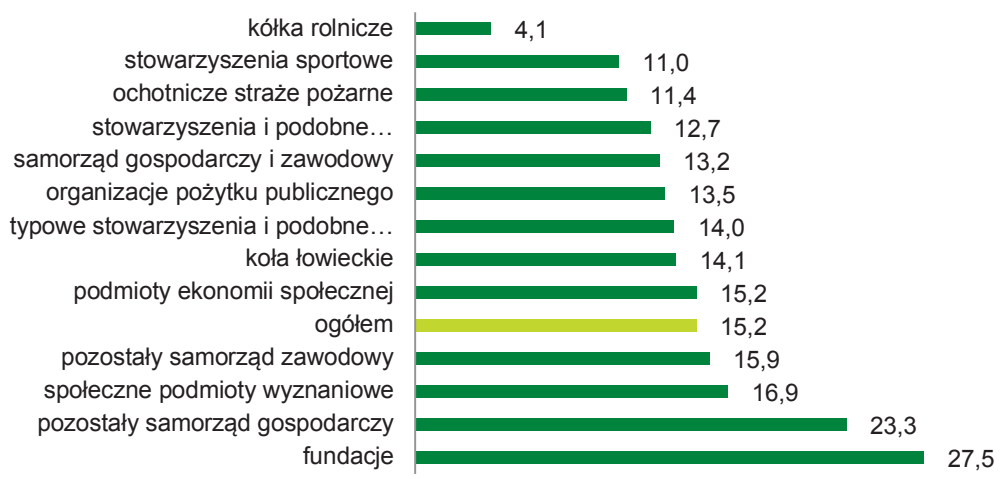

Ryc. 2. Forma prawna $\mathrm{NGO}^{2}$ w województwie mazowieckim (\%)

Źródło: opracowanie własne na podstawie: https://stat.gov.pl/obszary-tematyczne/gospodarka-spolecznawolontariat/gospodarka-spoleczna-trzeci-sektor/dzialalnosc-stowarzyszen-i-podobnych-organizacjispolecznych-fundacji-spolecznych-podmiotow-wyznaniowych-oraz-samorzadu-gospodarczegoi-zawodowego-w-2018-r-wyniki-wstepne,3,8.html

Wśród organizacji pozarządowych ponad 2/3 to stowarzyszenia, a blisko 1/3 fundacje. Inne podmioty stanowia tylko $2 \%$ liczby tych organizacji. Wyraźna przewaga stowarzyszeń jest wynikiem wielu czynników. Jednym z najważniejszych jest charakter członkostwa i zaangażowanie w działalność społeczną. Siła stowarzyszeń jest wola zrzeszania się i wspólne działanie zgodnie z własnymi przekonaniami i w społecznie istotnym celu. Brak wymogu kapitałowego charakterystycznego dla fundacji sprawia, iż realizacja celów społecznych

\footnotetext{
${ }^{2} \mathrm{NGO}$ - organizacja pozarządowa (ang. non-government organization, popularny skrót NGO) - organizacja działająca na rzecz wybranego interesu i niedziałająca w celu osiagnięcia zysku.
} 
w poczuciu spełnienia, uznania i satysfakcji daje efekt synergii, a potrzeby członków zbiorowości sa pełniej zaspokajane. Społeczności takie stają się przez to bardziej pluralistyczne. Stowarzyszenia, jako podmioty społeczeństwa obywatelskiego występują w różnych formach, co sprawia, że są wewnętrznie zróżnicowane. Struktura stowarzyszeń na Mazowszu ukazana została na rycinie 3 .

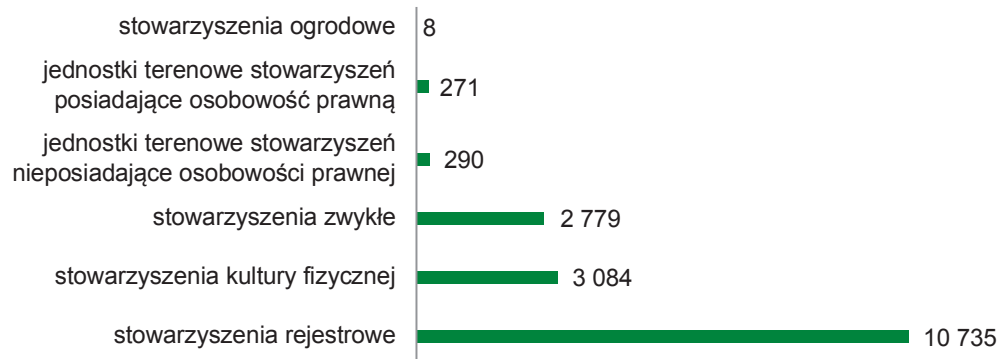

Ryc. 3. Rodzaje stowarzyszeń ${ }^{3}$ w województwie mazowieckim (dane w liczbach bezwzględnych)

Źródło: opracowanie własne na podstawie: https://stat.gov.pl/obszary-tematyczne/gospodarka-spolecznawolontariat/gospodarka-spoleczna-trzeci-sektor/dzialalnosc-stowarzyszen-i-podobnych-organizacjispolecznych-fundacji-spolecznych-podmiotow-wyznaniowych-oraz-samorzadu-gospodarczegoi-zawodowego-w-2018-r-wyniki-wstepne,3,8.html

Wśród nich zdecydowanie dominują stowarzyszenia rejestrowe, które stanowia ponad połowę wszystkich podmiotów w tej grupie. Drugą formą są stowarzyszenia kultury fizycznej (3084) a trzecią stowarzyszenia zwykłe (2779). Warto podkreślić, w kontekście rozwoju lokalnego i regionalnego, rolę jednostek terenowych, zarówno tych, które mają osobowość prawną (271), jak i tej osobowości niemających (290). Działając w konkretnym środowisku, w bliskości przestrzennej ze swoimi beneficjentami, nie tylko mają trafne rozeznanie potrzeb społecznych, ale także budują sieć powiązań i bliskość emocjonalna, tym samym pomnażając kapitał społeczny. Zróżnicowanie terytorialne stowarzyszeń, ze względu na ich dominujący udział w sektorze NGO w skali powiatów ukazuje obraz takiego sformalizowanego zaangażowania obywatelskiego (ryc. 4.).

Analizując liczebność stowarzyszeń w poszczególnych powiatach dokonano podziału na 4 przedziały nasycenia. Pierwszy, dominujący, stanowi m.st. Warszawa. Drugi przedział obejmuje jednostki administracyjne liczące od 371 do 526 stowarzyszeń. W tym przedziale znacząca liczba organizacji usytuowana jest w dwóch miastach: Radomiu i Płocku (odpowiednio: 526 i 422). Wysoki wskaźnik potencjału NGO, obserwujemy także w powiatach: piaseczyńskim, wołomińskim i mińskim (odpowiednio: 514, 432 i 385).

\footnotetext{
${ }^{3}$ Stowarzyszenie - organizacja społeczna powoływana przez grupę osób mających wspólne cele lub zainteresowania. Podstawowym aktem prawnym regulującym działalność stowarzyszeń, sposób ich zakładania i funkcjonowania jest ustawa z dnia 7 kwietnia 1989 r. - Prawo o stowarzyszeniach UPS (Dz.U. z 2020 r. poz. 2261).
} 


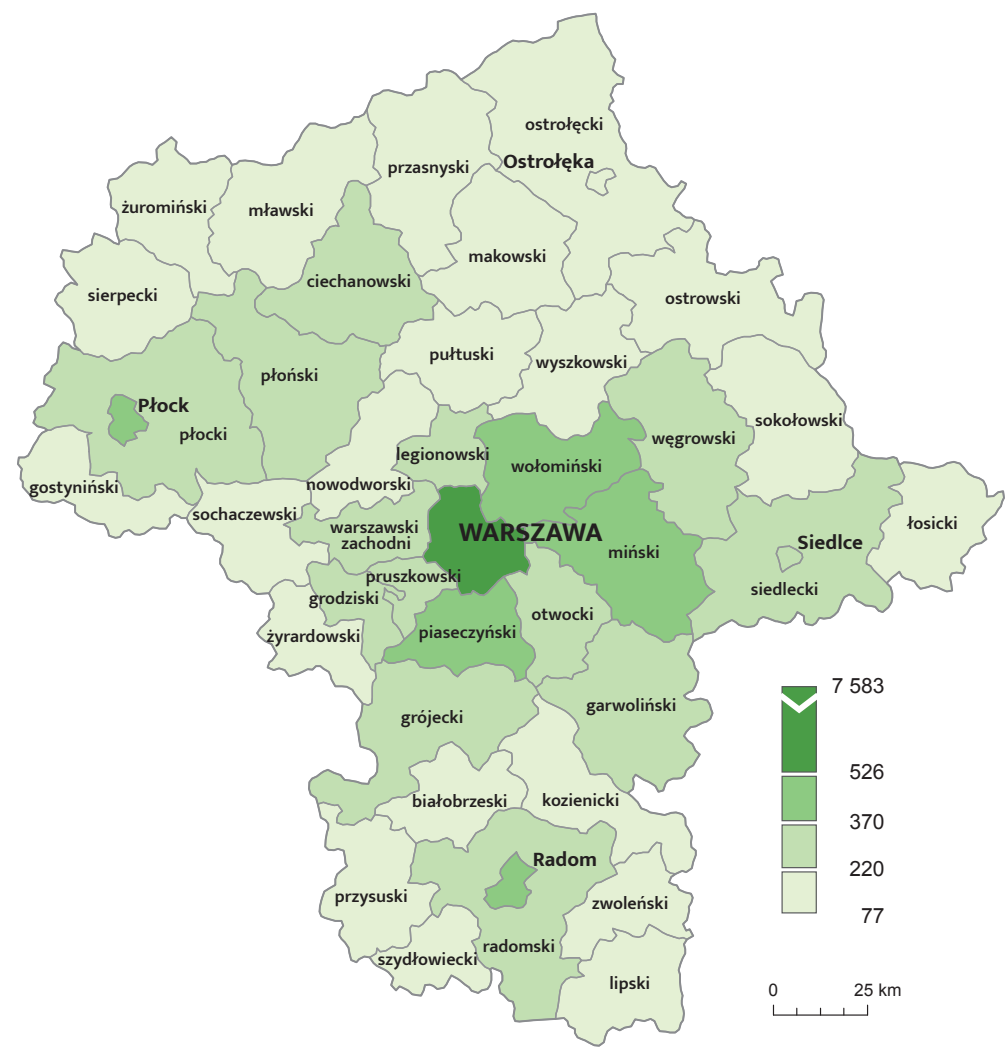

Ryc. 4. Forma prawna działających organizacji pozarządowych w podziale na powiaty - Stowarzyszenia

Źródło: opracowanie własne na podstawie: https://stat.gov.pl/obszary-tematyczne/gospodarka-spolecznawolontariat/gospodarka-spoleczna-trzeci-sektor/dzialalnosc-stowarzyszen-i-podobnych-organizacjispolecznych-fundacji-spolecznych-podmiotow-wyznaniowych-oraz-samorzadu-gospodarczegoi-zawodowego-w-2018-r-wyniki-wstepne,3,8.html

W trzeciej grupie znalazły się powiaty: pruszkowski (338), płocki (334), radomski (322), otwocki (308), legionowski (285), warszawski zachodni (275), ciechanowski (265), siedlecki (263), m. Siedlce (256), garwoliński (254), grójecki (251), węgrowski (242) i płoński (233).

Pozostałe powiaty mieszczą się w najniższym przedziale (od 72 do 220 stowarzyszeń), co wskazuje na niewysoki poziom woli ich mieszkańców do sformalizowanego zrzeszania się $\mathrm{w}$ organizacjach pozarządowych.

Grupę podmiotów trzeciego sektora o istotnej skali i znaczeniu w wielosektorowej polityce rozwoju stanowią fundacje. Chociaż nie są one organizacjami członkowskimi, to stanowią jednak płaszczyznę zarówno do indywidualnej ekspresji, jak i zaangażowania w pracę społeczną (ryc. 5). 


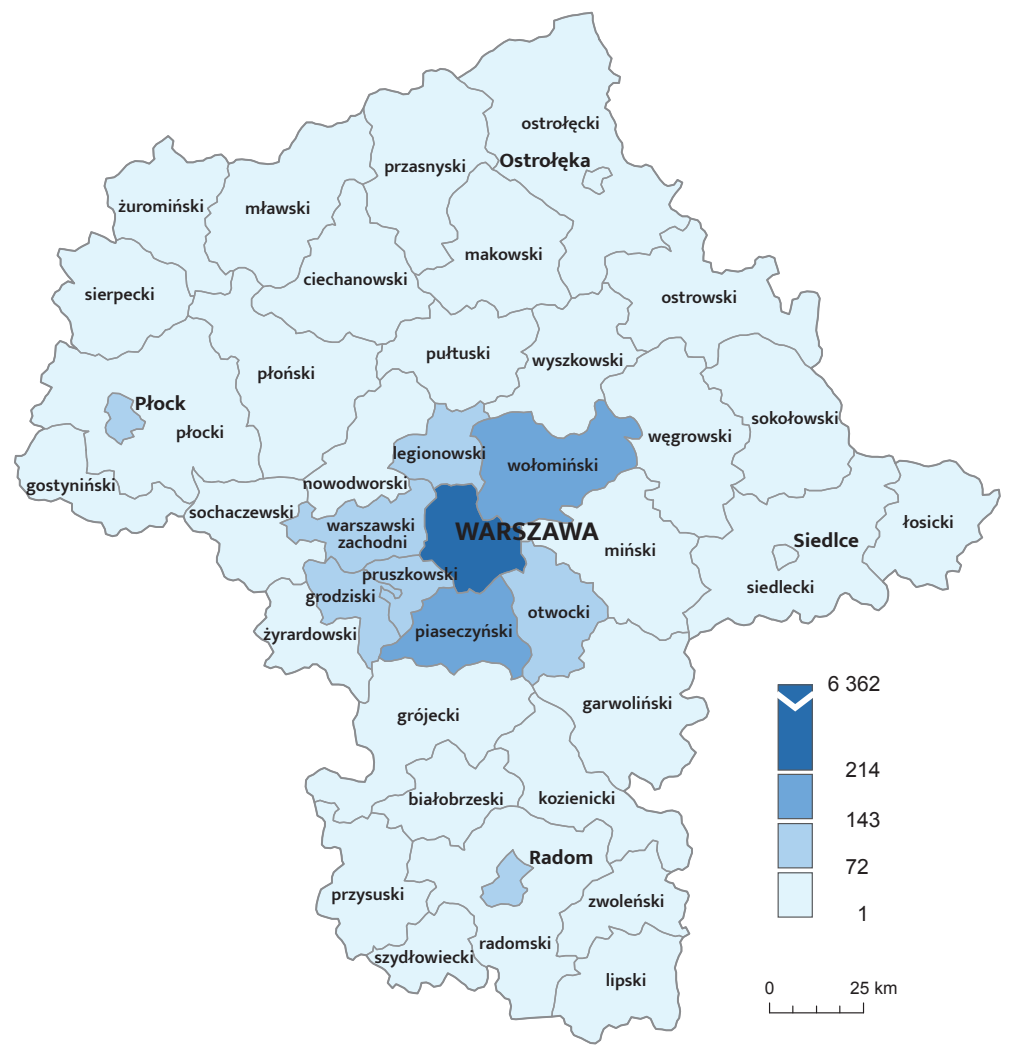

Ryc. 5. Forma prawna działających organizacji pozarządowych w podziale na powiaty - Fundacje

Źródło: opracowanie własne na podstawie: https://stat.gov.pl/obszary-tematyczne/gospodarka-spolecznawolontariat/gospodarka-spoleczna-trzeci-sektor/dzialalnosc-stowarzyszen-i-podobnych-organizacjispolecznych-fundacji-spolecznych-podmiotow-wyznaniowych-oraz-samorzadu-gospodarczegoi-zawodowego-w-2018-r-wyniki-wstepne,3,8.html

W województwie mazowieckim zarejestrowanych jest, wg danych GUS, 7974 fundacje. Podobnie jak w przypadku innych form organizacyjnych trzeciego sektora dominuje miasto stołeczne. W Warszawie ma swoje siedziby aż 6362 fundacje, co stanowi prawie $80 \%$ wszystkich tego rodzaju podmiotów działających w województwie. Analizując strukturę terytorialną takich podmiotów jak fundacje, widać wyraźnie efekt promieniowania miasta stołecznego oraz wielkości ośrodków miejskich. Poza Radomiem i Płockiem, pozostałe powiaty o wyższym nasyceniu stanowią sąsiedztwo Warszawy (wyjątek powiat miński). Wśród nich najwyższa liczebność fundacji występuje w powiatach piaseczyńskim i wołomińskim (214 i 144). Przeciętny dla województwa poziom mieszczący się w przedziale 73 do 143 charakteryzuje powiaty legionowski, pruszkowski, warszawski zachodni, oraz otwocki, a także dwa miasta: Radom i Płock. Pozostałe powiaty województwa mają niewielką liczbę fundacji.

Wśród zaprezentowanych powyżej organizacji pozarządowych występuja takie, które posiadają status organizacji pożytku publicznego. Ustawa z dnia 24 kwietnia 2003 r. 
o działalności pożytku publicznego i wolontariacie znowelizowana ustawą z dnia 22 stycznia 2010 r. o zmianie ustawy o działalności pożytku publicznego i o wolontariacie oraz niektórych innych ustaw (Dz.U. z 2010 r. nr 28, poz. 146), określa istotę działalności pożytku publicznego, jako takiej, która „jest społecznie użyteczna, prowadzona przez organizacje pozarządowe w sferze zadań publicznych" [Arczewska 2007, s. 9]. Jest to kluczowe dla określenia roli tych organizacji w sferze publicznej. Pożytek publiczny bywa rozumiany wieloaspektowo jako:

- każde działanie społecznie użyteczne,

- dostarczanie obywatelom konkretnych usług czy świadczeń,

- dostarczanie pewnych usług tylko na zewnatrz danej organizacji (jej członkowie nie korzystają z nich - przynajmniej - bezpośrednio) [Gliński 2006, s. 18].

Status organizacji pożytku publicznego przynosi tym podmiotom szereg korzyści, nakłada też na nie wiele nowych obowiązków, m.in. sporządzenia i zatwierdzenia rocznego sprawozdania finansowego oraz rocznego sprawozdania merytorycznego. Organizacje, które aspirują do takiego statusu muszą znacząco podnosić poziom profesjonalizmu podejmowanych działań. Z perspektywy kontroli społecznej zapewniona jest przez to większa transparentność działań organizacyjnych.

Na początku 2020 r. w woj. mazowieckim istniało 1395 Organizacji Pożytku Publicznego $^{4}$ (ryc. 6, 7). Dane GUS, będące podstawową bazą tej analizy, dotyczące liczby OPP mówią o 1380 jednostkach. Biorąc pod uwage ich formę prawna, możemy je podzielić podobnie jak organizacje pozarządowe. Warto również podkreślić, iż od 2004 r. możemy zaobserwować stały, dynamiczny wzrost zarówno liczby OPP, jak i kwoty przekazanych podatków w całym kraju.

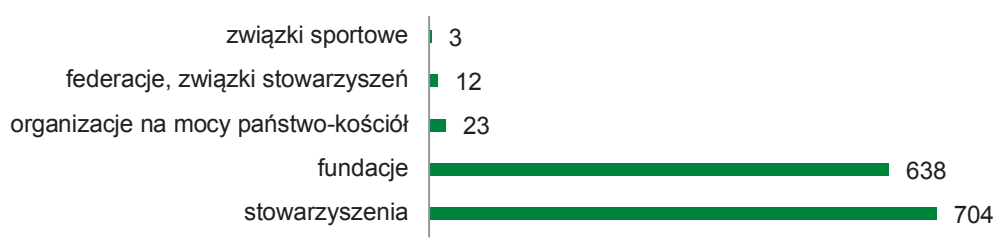

Ryc. 6. Forma prawna OPP5 w województwie mazowieckim

Źródło: opracowanie własne na podstawie: https://stat.gov.pl/obszary-tematyczne/gospodarka-spolecznawolontariat/gospodarka-spoleczna-trzeci-sektor/dzialalnosc-stowarzyszen-i-podobnych-organizacjispolecznych-fundacji-spolecznych-podmiotow-wyznaniowych-oraz-samorzadu-gospodarczegoi-zawodowego-w-2018-r-wyniki-wstepne,3,8.html.

\footnotetext{
${ }^{4}$ http:/ / www.podatki.egospodarka.pl/opp/mazowieckie/

${ }^{5}$ OPP - Organizacja pożytku publicznego (OPP) - termin wprowadzony w Polsce 1 stycznia $2004 \mathrm{r}$. przepisami ustawy o działalności pożytku publicznego i o wolontariacie. Status OPP może uzyskać organizacja pozarządowa (z wyjątkiem partii politycznych i należących do nich fundacji, związków zawodowych, organizacji pracodawców oraz samorządów zawodowych), jak również spółka kapitałowa powołana w celu niezwiązanym z prowadzeniem działalności gospodarczej, jeżeli prowadzi przez
} 
Analizując strukturę terytorialną organizacji pożytku publicznego znów widać wyraźnie efekt promieniowania miasta stołecznego oraz znaczenie wielkości ośrodków miejskich. W Warszawie funkcjonują 924 organizacje pożytku publicznego. Poza Radomiem i Płockiem, w których działa odpowiednio: 42 i 30 takich podmiotów, pozostałe powiaty o wyższym nasyceniu stanowią sąsiedztwo Warszawy. Najwyższą wśród nich liczbą OPP może

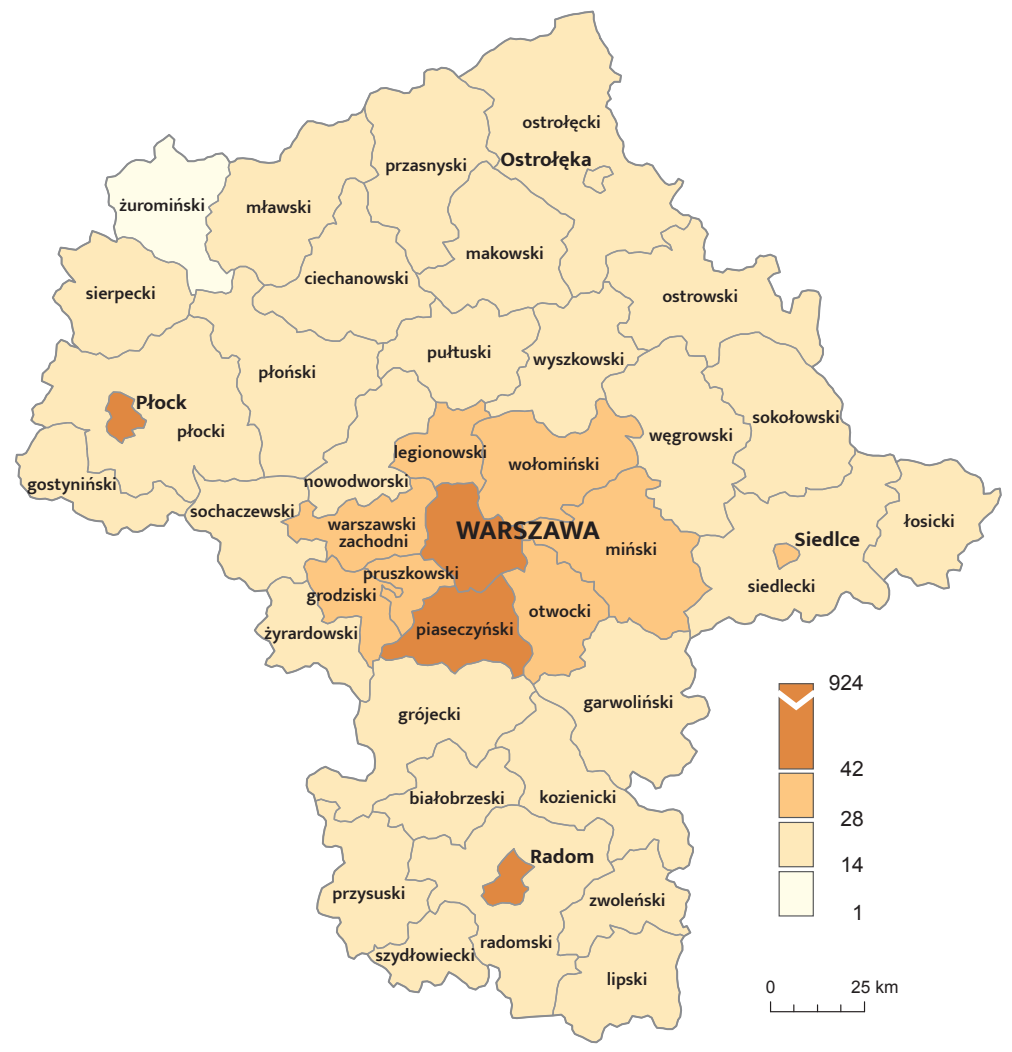

Ryc. 7. Forma prawna działających organizacji pozarządowych w podziale na powiaty - OPP

Źródło: opracowanie własne na podstawie: https://stat.gov.pl/obszary-tematyczne/gospodarka-spolecznawolontariat/gospodarka-spoleczna-trzeci-sektor/dzialalnosc-stowarzyszen-i-podobnych-organizacjispolecznych-fundacji-spolecznych-podmiotow-wyznaniowych-oraz-samorzadu-gospodarczegoi-zawodowego-w-2018-r-wyniki-wstepne,3,8.html

co najmniej dwa lata działalność w obszarach tzw. pożytku publicznego, które zostały określone ustawa o działalności pożytku publicznego i o wolontariacie. Ponadto organizacja musi spełniać dodatkowe kryteria, dotyczace m.in. jawności działania, kontroli w organizacji. Status OPP nadaja organizacjom wydziały gospodarcze Krajowego Rejestru Sądowego sądów rejonowych odpowiednich dla adresu siedziby organizacji. 
wykazać się powiat piaseczyński, a poza nim w trzecim przedziale z wysoka, w porównaniu z przeciętną dla województwa, ich liczbą znajdują się takie powiaty jak: legionowski, pruszkowski, grodziski, warszawski zachodni, miński i wołomiński oraz otwocki. Pozostałe powiaty mają niewielką liczbę organizacji pożytku publicznego. Należy podkreślić, iż o status organizacji pożytku publicznego zdecydowanie częściej ubiegają się stowarzyszenia niż fundacje, dla których jest to istotna możliwość ubiegania się o środki na własna działalność.

Podobnie jak w przypadku ogólnej liczby organizacji pozarządowych, nieco odmienny obraz zaangażowania $w$ tę formę funkcjonowania trzeciego sektora uzyskamy, gdy przeanalizujemy ich liczbę na 10000 mieszkańców.

Nie jest zaskoczeniem, że znowu największy wskaźnik charakteryzuje miasto stołeczne. Tam na wskazaną liczbę mieszkańców przypada 5,4 podmiotów, a średnia dla województwa mazowieckiego wynosi 2,55. Mediana powyższego wskaźnika wynosi już tylko 1,12. Tutaj więc również m.st. Warszawa zdecydowanie zawyża statystyki.

W odniesieniu do innych miast i powiatów województwa obraz tej aktywności jest zdecydowanie odmienny. Pomimo mniejszej liczby bezwzględnej organizacji pożytku publicznego - wśród miast - najwyższy wskaźnik odnotowujemy w Siedlcach $(2,70)$, zaś miasto Płock przewyższa w tym względzie Radom (odpowiednio: 2,48 i 1,96). Także miasto Ostrołęka osiaga jeden z wyższych wskaźników (1,72). Wskazane we wcześniejszym zestawieniu powiaty z relatywnie wyższą liczbą organizacji pożytku publicznego na swoim terenie: legionowski, pruszkowski, grodziski, warszawski zachodni, miński i wołomiński mieszczą się w przedziale między 1,00 a 2,00 co jednak znacząco odbiega od wskaźnika najlepszego (poza Warszawa) miasta w regionie, jakim w tym zestawieniu okazały się Siedlce.

Należy również zwrócić uwagę na te powiaty, w których deficyt liczby organizacji pożytku publicznego na 10000 mieszkańców jest szczególnie duży. Należą do nich: powiat żuromiński, w którym żaden taki podmiot w ogóle nie występuje oraz powiaty: łosicki, ostrołęcki, przasnyski i płoński, w których wskaźnik waha się między 0,32 a 0,36 i wyraźnie odbiega od mediany (ryc. 8).

W sumie, w wyniku analizy potencjału zaangażowania obywatelskiego w województwie mazowieckim wyraźnie widać, że zdecydowanie dominuje tu miasto stołeczne. Przypatrując się liczbie NGO według podziału na powiaty widzimy, że ponad połowa wszystkich organizacji znajduje się w Warszawie, a w przeliczeniu na 10000 mieszkańców przypada ich około 43.

W skali całego kraju województwo mazowieckie może pochwalić się największą liczba organizacji w liczbach bezwzględnych, jak i w ich liczbie na 10000 mieszkańców. Co ciekawe, mediana dla całego województwa pokazuje wartość 33,11. Widoczny na to wpływ ma pozycja lidera m.st. Warszawy, które zdecydowanie zawyża statystyki województwa. Najniższy wskaźnik w tym zakresie występuje w powiatach: zwoleńskim $(21,58)$, przasnyskim $(20,15)$, oraz mławskim $(12,55)$. 


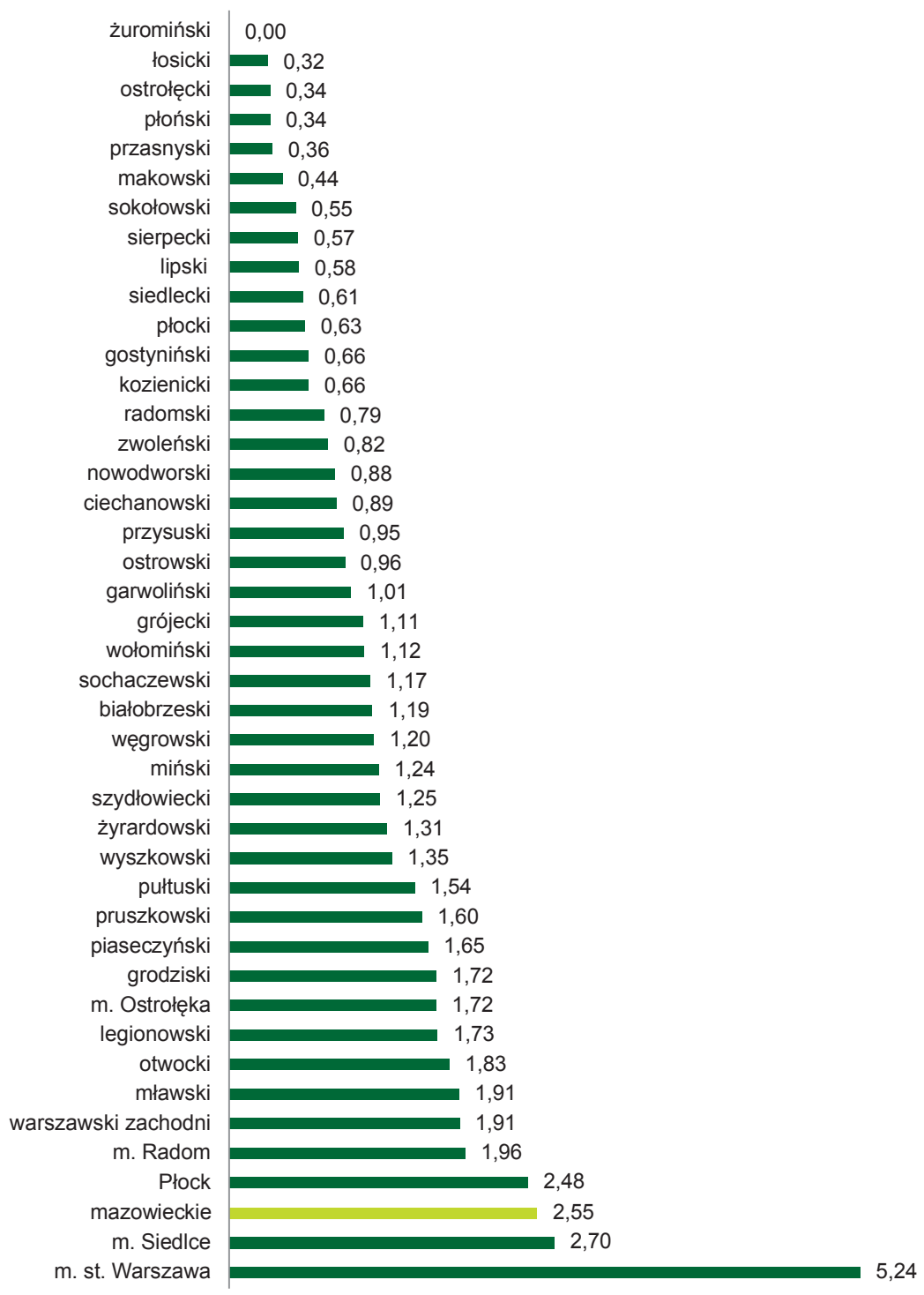

Ryc. 8. Liczba OPP w wojojewództwie mazowieckim na 10 tys. mieszkańców w podziale na powiaty

Źródło: opracowanie własne na podstawie: https://stat.gov.pl/obszary-tematyczne/gospodarka-spolecznawolontariat/gospodarka-spoleczna-trzeci-sektor/dzialalnosc-stowarzyszen-i-podobnych-organizacjispolecznych-fundacji-spolecznych-podmiotow-wyznaniowych-oraz-samorzadu-gospodarczegoi-zawodowego-w-2018-r-wyniki-wstepne,3,8.html 


\section{Podsumowanie}

Pomimo dość powszechnego poparcia dla idei rozwoju zrównoważonego i jej zasad oraz pluralizmu w politykach publicznych implementacja ich założeń w praktyce jest niezmiernie trudna we wszystkich obszarach funkcjonowania społeczeństw i gospodarek. Także prowadzenie wielosektorowej, odpowiedzialnej polityki rozwoju regionalnego i lokalnego - zgodnej z zasadami trwałego i zrównoważonego rozwoju nastręcza wiele trudności. Oddziaływanie polityk publicznych w wielu regionach jest złożone, gdyż nakładają się na siebie oddziaływania przyrodnicze, gospodarcze, społeczne i kulturowe. Także istnienie wielu wizji zaangażowania trzeciego sektora $\mathrm{w}$ politykę rozwoju nie sprzyja jednoznacznemu wzrostowi aktywności społecznej w tej sferze.

Przedstawione w opracowaniu zróżnicowanie terytorialne instytucjonalnego zaangażowania społecznego pokazuje, iż w wielu powiatach współpraca sektorowa jest ograniczona ze względu na niewielką liczbę podmiotów mogących realizować zadania zlecane przez podmioty samorządowe. Co prawda, województwo mazowieckie poszczycić się może największą liczba podmiotów mających osobowość prawna, to jednak połowa organizacji pozarządowych w województwie mazowieckim, to jednostki z siedziba na terenie Warszawy, a blisko $1 / 4$ wszystkich fundacji działających w kraju zlokalizowana jest w stolicy. Ilościowy obraz podmiotów z siedziba w Warszawie znacząco zaburza obraz funkcjonowania stowarzyszeń, fundacji jak i organizacji mających status pożytku publicznego w skali województwa. Szczególnie istotne wydaje się spowolnienie wzrostu liczby podmiotów mających status organizacji pożytku publicznego w powiatach. Organizacje te sa ważnym partnerem w procesie uspołeczniania współrządzenia. Status organizacji pożytku publicznego przynosi tym podmiotom szereg korzyści, nakłada też na nie wiele nowych obowiązków, m.in. sporządzenia i zatwierdzenia rocznego sprawozdania finansowego oraz rocznego sprawozdania merytorycznego. Organizacje muszą systematycznie podnosić poziom profesjonalizmu podejmowanych działań. Z perspektywy kontroli społecznej zapewniona jest przez to większa transparentność działań organizacyjnych, a dla samorządów są gwarantem jakości realizowanych zadań zleconych.

Bez względu na poziom trudności idea współrządzenia zaangażowanych podmiotów obywatelskich wymaga upowszechnienia i promocji tak, aby w sposób świadomy i celowy prowadzić do pożądanych przemian postaw i systemów wartości mieszkańców, przedstawicieli trzeciego sektora i społeczności lokalnych w duchu zrównoważonego rozwoju. Tworzenie struktur NGO, zaangażowanych w działania społeczne, prowadzi też do identyfikacji jednostek ze zbiorowością i dobrem wspólnym oraz intensyfikacji działań w sferze społecznej i indywidualnej [Gagacka 2008, s. 143-168].

Unia Europejska uczyniła z rozwoju regionalnego jeden z podstawowych filarów spójności Wspólnoty, wychodząc z założenia, że władze lokalne i regionalne odgrywają dominująca rolę w procesach modernizacyjnych i rozwojowych. Obarczono je zatem szczególną rola i odpowiedzialnością w kreowaniu wizji i warunków dla tych procesów. 
Ważną rolę we współczesnych koncepcjach rozwoju regionalnego odgrywają czynniki wewnętrzne. Czynniki zewnętrzne postrzegane są z tej perspektywy w roli akceleratora rozwoju. Wymogiem rozwoju endogennego jest zatem szerokie w nim uczestnictwo społeczeństwa, a także wyzwolenie w nim energii i kreatywności.

Rozwój endogenny na poziomie regionalnym ujmowany jest jako proces, w którym znacząca rolę odgrywaja potrzeby i inicjatywy oraz kompetencje członków społeczności, zaś impulsami rozwojowymi są uwarunkowania kulturowe oraz możliwości i realia regionów.

Podmioty społeczeństwa obywatelskiego stanowia niezbędny instrument w polityce regionalnej, wzbogacający jej przestrzeń i cele nie tylko o te oddziaływania, które kształtują warunki życia, lecz także umacniają więzi społeczne. Pluralistyczna polityka regionalna może stać się narzędziem budowy i umacniania społeczeństwa obywatelskiego. Aktywność publiczna jest korzystna obustronnie, zwiększa efektywność organów statutowo odpowiedzialnych za dostarczanie usług publicznych, zaś z drugiej strony aktywni obywatele lepiej zaspokajają swoje potrzeby. W obopólnym interesie należy wspierać działania i przekształcenia trzeciego sektora. Jakość życia obywateli i jakość rządzenia warte są stałych, systematycznych działań.

\section{Materiały źródłowe}

\section{Literatura}

Arczewska M., 2007, Nie tylko jedna ustawa. Prawo o organizacjach pozarzadowych, Instytut Spraw Publicznych, Warszawa.

Barański M., Kantyka S., Kubas S., M. Kuś, 2007, Samorzq̨d terytorialny i wspólnoty lokalne, Wydawnictwo Komandor, Warszawa.

Defourny J., 2004, Introduction: from third sector to social enterprise [w:] C. Borzga, J. Defourny (red.), The emergency of social enterprises, Routledge, London, New York.

Evers A., Laville J.L., 2004, Defining the third sector in Europe [w:] The third sector in Europe, Cheltenham UK, Northampton, MA, USA.

Gagacka M., 2007, Rola organizacji pozarządowych w rozwoju lokalnym [w:] K. Piątek, A. Karwacki (red.), Aktywna polityka społeczna z perspektywy Europy socjalnej, Wydawnictwo Edukacyjne AKAPIT, Toruń.

Gagacka M., 2008, Wsparcie społeczne. Wartość czy instrument w lokalnej polityce społecznej? [w:] K. Głąbicka, M. Grewiński (red.), Wokót polityki społecznej, TWP, Warszawa.

Gagacka M., 2009, Nierówności społeczne jako wyzwanie dla ekonomii społecznej [w:] M. Gagacka, K. Głąbicka (red.), Współczesne wyzwania dla lokalnej polityki społecznej, Wydawnictwo PTPS i Politechniki Radomskiej, Radom. 
Gąciarz, J. Bartkowski, 2012, Samorząd a rozwój. Instytucje, obywatele, podmiotowość, Instytut Filozofii i Socjologii PAN, Warszawa.

Gliński P., 2006, Style działań organizacji pozarzadowych w Polsce. Grupy interesu czy pożytku publicznego, Instytut Filozofii i Socjologii PAN, Warszawa.

Grewiński M., 2006, Wielosektorowa polityka społeczna - w kierunku welfare pluralism, Polityka Społeczna, $5 / 6$.

GUS, 2019, Działalność stowarzyszeń i podobnych organizacji społecznych, fundacji, społecznych podmiotów wyznaniowych oraz samorzadu gospodarczego i zawodowego w 2018 r., Raport - wyniki wstępne, GUS, Warszawa.

Herbst M., 2007, Kapitał ludzki i kapitał społeczny a rozwój regionalny, Wydawnictwo Naukowe Scholar, Warszawa.

Hrynkiewicz J., 2002, Rola organizacji obywatelskich w polityce społecznej [w:] J. Hrynkiewicz (red.), Przeciw ubóstwu i bezrobociu: lokalne inicjatywy obywatelskie, Instytut Spraw Publicznych, Warszawa.

Krzysztofek K., Szczepański M., 2002, Zrozumieć rozwój. Od społeczeństw tradycyjnych do informacyjnych, Wydawnictwo Uniwersytetu Śląskiego, Katowice.

Kuti E., 1989, Te possible role $f$ the nonprofit sector in Hungary, Johns Hopkins University, Baltimore.

Kwilecki A., 1992, Region i badania regionalne w perspektywie socjologii, Ruch Prawniczy, Ekonomiczny i Socjologiczny, 54, 2.

Leś E., 2018, Rola organizacji społecznych w świadczeniu usług zinstytucjonalizowanych [w:] G. Firlit-Fesnak, J. Męcina (red.), Polityka społeczna, Wydawnictwo Naukowe PWN, Warszawa.

Piekara A., 1991, Aksjologiczne i pragmatyczne aspekty samorzadu terytorialnego, Samorząd terytorialny, $1 / 2$.

Salomon L, H.K. Anheier, 1992, In search of the nonprofit sector: the question of definitions, Voluntas, 2, 3.

Seidel W., Anheier H.K., 1990, Sociological and political approaches to the third sector, [w:] H.K. Anheier, W. Seidel (red.), The Third Sector Comparative Studies Nonprofit Organizations, Walter de Gryeter, Berlin - New York.

Supińska J., 2009 Podmioty polityki społecznej - współzawodnictwo, wspótistnienie, wspótpraca [w:] M. Księżopolski, B. Rysz-Kowalczyk, C. Żołędowski (red.), Polityka społeczna w kryzysie, Wydawnictwo ASPRA-JR, Warszawa.

Tomaszewski K., 2007, Regiony w procesie integracji europejskiej, Wolters Kluwer Polska, Warszawa. 


\section{Strony internetowe}

https: / / stat.gov.pl/ obszary-tematyczne / gospodarka-spoleczna-wolontariat/gospodarka-spoleczna-trzeci-sektor / dzialalnosc-stowarzyszen-i-podobnych-organizacji-spolecznychfundacji-spolecznych-podmiotow-wyznaniowych-oraz-samorzadu-gospodarczego-izawodowego-w-2018-r-wyniki-wstepne,3,8.html [dostęp: sierpień 2021].

https: / / publicystyka.ngo.pl/ sektor-pozarzadowy-w-2018-ile-jest-w-polsce-organizacji [dostęp: sierpień 2021].

https: / / api.ngo.pl/media / get/108904 [dostęp: sierpień 2021]. 


\section{Multi-sectoral cooperation in creating the regional development of the Mazowieckie Voivodeship}

\section{ABSTRACT}

The development aspirations of modern societies have often a conflict nature. Creating a vision for development in the face of clashes with immediate economic goals, both at the level of public policies and the interests of individual entities and social groups, poses increasing difficulties. It also requires searching for new forms of solving social problems.

In Poland, problems with the implementation of the idea of development based on intersectoral cooperation are associated with regional differentiation, as well as differentiation within regions. The appearance of the third sector in the development policy at the regional level - next to the public and private sphere - has contributed to the search for innovative forms of cooperation and new methods of solving social issues. The aim of this paper is to analyse the scale of the third sector involvement and its role in building regional development policy of the Mazowieckie Voivodeship.

Key words: regional development, public policy, intersectoral cooperation, third sector, Mazowieckie Voivodeship

\footnotetext{
Maria Gagacka, dr - adiunkt w Katedrze Nauk o Państwie i Polityce Społecznej, ekspert Polskiego Towarzystwa Polityki Społecznej, członek Rady Rozwoju przy Prezydencie Miasta Radomia. Zainteresowania badawcze: polityki publiczne, wielosektorowa polityka społeczna, aktywność obywatelska i usługi społeczne.

Maria Gagacka, PhD - Assistant Professor at the Department of State and Social Policy Sciences, expert of the Polish Society for Social Policy, member of the Development Council at the Mayor of Radom. Research interests: public policies, multi-sectoral social policy, civic engagement and social services.
} 